\title{
MULTICULTURAL COMPETENCIES OF TEACHERS AND TEACHER TRAININGS ON DIVERSITY/MULTCULTURALISM FOR INCLUSIVE SCHOOLS AND THE INCLUSION OF ROMA AND MIGRANT CHIDREN - PROJECT ROMIGSC AS CASE STUDY

\author{
Nada Trunk Šrca ${ }^{1}$, Valerij Dermol ${ }^{2}$, Anica Novak Trunk ${ }^{3}$
}

\begin{abstract}
Education is a public good and a human right. Access to inclusive, equitable and good quality educational opportunities and assistance for all learners of any age needs to be ensured. Indeed, they are a precondition for social inclusion and protection, full participation in social and civic spheres of life, long-term integration into the labour market and the prevention of exploitation.

In this paper, we discuss the importance of multicultural competencies of teachers and the role of formations/ teacher trainings to support inclusion in schools - with a focus on Roma and migrant children. The aim of this paper is to give an overview on the current situation regarding multicultural competencies and trainings/formations for teachers in Slovenia; and to present how participants of trainings for teachers (training in frame of project RoMigSc) see inclusion of Roma/migrants in Slovenian schools; and how important are teachers' competencies for supporting inclusion. The methods used in this study are literature review, small-scale research among participants of teacher training in Slovenia in 2017 and 2018; and policy formulations from deliveries of teacher trainings in four countries - Slovenia, Italy, Spain and North Macedonia. The results from the small-scale research show that most of participants were teachers; $66 \%$ of respondents had been involved in work with migrant children; $52 \%$ in work with Roma children. Respondents were in general very satisfied with the training delivery. Lessons learned which they liked the most refer to the involvement of different actors in ensuring inclusion; networking; and transfer of experience. The results also show that multicultural competencies of teachers and teacher trainings on diversity/multiculturalism are of key importance for supporting the inclusion of Roma/migrant children. From the results of the small-scale research and policy formulations (from four countries), we can conclude that intercultural competencies and high quality implementation of formations/teacher trainings are of key importance for supporting the inclusion of Roma/migrants in schools.
\end{abstract}

UDC Classification: 37.06 , DOI: 10.12955/cbup.v7.1436

Keywords: Social inclusion in schools, project RoMigSc, teachers' multicultural competencies.

\section{Introduction}

Education (i.e., good teachers and good schools) is crucial for successful integration of Roma and migrants in society. Multicultural diversity is an opportunity to make schools more inclusive, creative and open-minded.

Education is a public good and a human right. Access to inclusive, equitable and good quality educational opportunities and assistance for all learners of any age needs to be ensured. Indeed, they are a precondition for social inclusion and protection, full participation in social and civic spheres of life, long-term integration into the labour market and the prevention of exploitation.

Educational systems play an important role in helping pupils with immigrant backgrounds get involved in their communities and overcome problems. The introduction of an early assessment of language and other skills, the provision of targeted language training, ensuring availability and participation in activities and the involvement of parents can improve the well-being of pupils with an immigrant background in all its fields (OECD, 2018).

In this paper, main attention will be paid to the importance of teachers' multicultural competencies and trainings/formations for ensuring better inclusion of Roma/migrant children in schools.

\section{Multiculturalism in education}

The model of development of multicultural competencies

In order that teachers are able to apply the principle of multi-culturalism in education, they must on the one hand, achieve high professional competence in the field of the subject matter they are teaching, and at the same time they have to deal with ethnic values, religious values, cultural values; and the differences (and take them into account) that they encounter in the class. This means that they must have developed intercultural competencies.

Below is presented the model of development of multicultural competencies (developed by Deardorff, 2006); Through this model, Bešter and Medvešek (2016) researched multicultural competencies of

\footnotetext{
${ }^{1}$ University of Primorska, Faculty of Management Koper \& International School for Social and Business Studies, Celje, Slovenia, trunk.nada@gmail.com

${ }^{2}$ International School for Social and Business Studies, Celje, Slovenia, valerij.dermol@siol.net

${ }^{3}$ Institute for Romological Studies, Education and Culture, Murska Sobota, Slovenia, anicanovak@yahoo.co.uk
} 
Slovenian teachers at their work with Roma children. The model of development of multicultural competencies is composed of four areas:

- Attitude toward others/diversity

- Knowledge, understanding, skills

- Intercultural reflection that presents the wanted internal result

- Constructive interactions, that presents the wanted external result

The more positive attitude a person has toward cultural diversity, the more knowledge he acquires and, in doing so, develops the necessary skills. We can assume that all four dimensions affect each other.

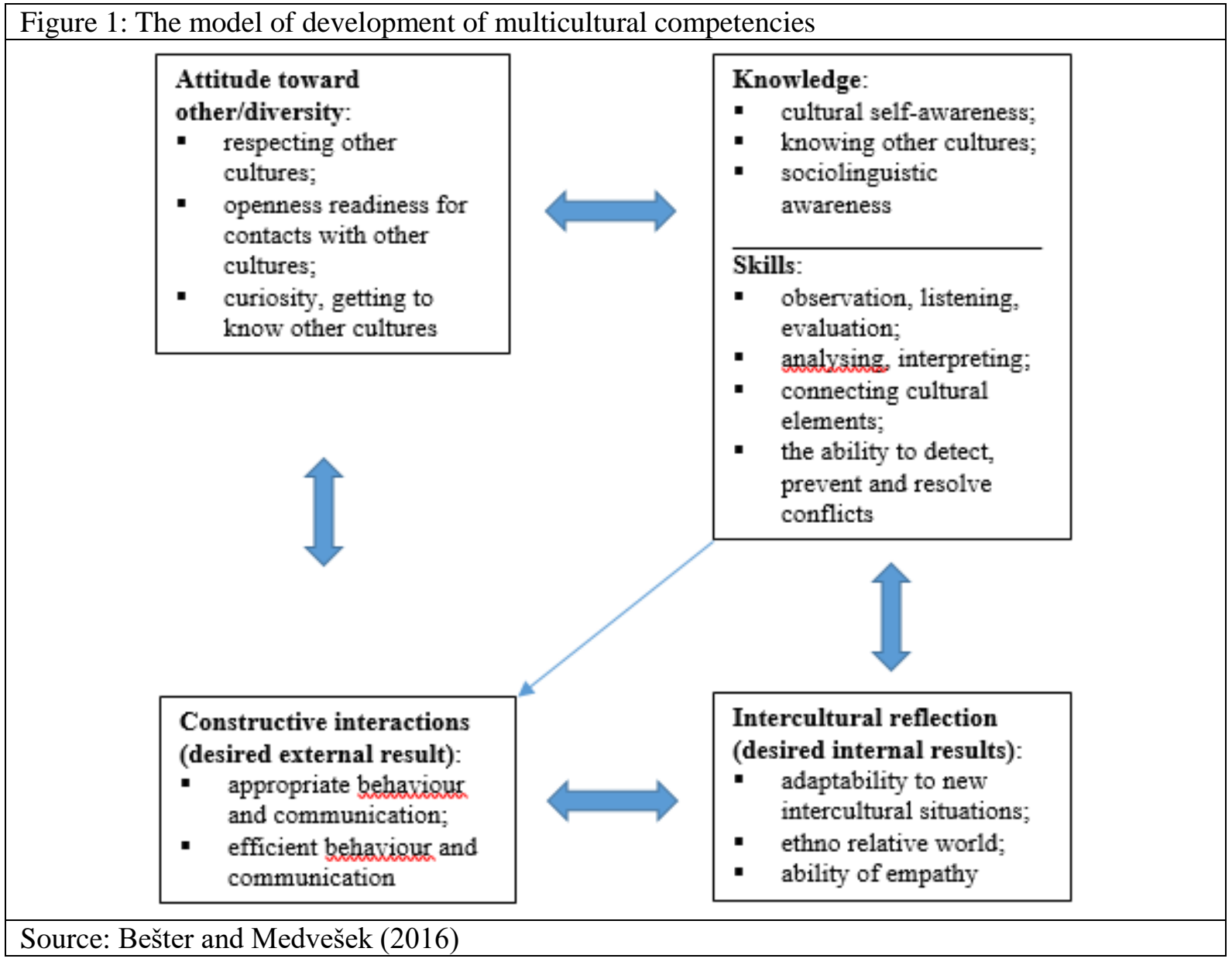

Studies that were made until 2010 show that Slovenian teachers have a lack of necessary knowledge and experience in the field of intercultural education - the latter is the result of a lack of trainings for the development of competencies to successfully manage multicultural dynamics in the classroom (Trunk, Kočar and Trunk Širca, 2017). Research - such as TALIS (OECD, 2009) also showed that Slovenian teachers showed relatively little interest in participating in training on "teaching in multicultural environments." In order to contribute to the development of the values of inter-culturalism and to improve the professional skills of leadership and teachers in schools for the successful integration of migrant children from other linguistic and cultural backgrounds in the Slovenian education system, a number of projects were launched from 2013 onwards.

Below we present some projects:

In the period from 2013 to 2015 was implemented the project Razvijamo medkulturnost kot novo obliko sobivanja / Inter-culturalism as a new form of coexistence. The consortium involved 13 primary schools and the ISA institute. The network involved 62 schools (primary and secondary) altogether (ISA, 2015). In the year 2016/17, two big projects began, which aimed at enhancing teachers competencies (Ministry of Education, Science and Sport, Republic of Slovenia, 2019): 
- Project Izzivi medkulturnega sobivanja-Za medkulturno sobivanje / Challenges of Intercultural Coexistence 2016-2021 (is continuation of the project Razvijamo medkulturnost kot novo obliko sobivanja / Inter-culturalism as a new form of coexistence). The consortium involves 15 primary and secondary schools and the ISA institute.

- Project Le z drugimi smo / Only (with) others are we (2016-2021) - different seminars on interculturalism will be organised in all Slovenian regions.

However, in this area improvements still need to be done like:

- training programmes should include diversity on a transversal basis, rather than limiting it to specific modules, which has also been suggested by the European Parliament, 2017.

- contents on inter-culturalism should be systematically involved in study programmes for teachers.

\section{Research conducted in the frame of trainings for teachers RoMigSc in Slovenia in 2017 and in 2018}

About teacher training in the frame of the project RoMigSc

Main aim of teacher training RoMigSc is:

- to ensure better cultural competencies of teachers that teach in classes where Roma or migrant children are and to give them knowledge on strategies for inclusion of these groups in classrooms;

- to receive the following feedback from teachers: what is good in the system of inclusion of disadvantaged pupils (Roma/migrants) in school; where are shortcomings perceived (deficits) and where are improvements needed.

In the years 2017, 2018, 2019, teacher trainings are organised as 2 day events (of 16 hours in total), covering the topics: social inclusion, inclusion in schools - specifics migrants; specifics Roma, intercultural competencies, youth activation. In 2017, trainings were organised only in Slovenia (piloted), while in 2018 and 2019 trainings were organised in four countries: Slovenia, Italy, Spain, FYROM.

Analysis of questionnaire

Below we present an analysis of the questionnaire on the topic of integration of migrants and Roma into schools, which was conducted in the frame of the Erasmus +, K3 project RoMigSc. The questionnaire was conducted with participants of teacher trainings 2017 and 2018 in Slovenia.

In 2017, the questionnaire was sent to 54 participants of teachers' trainings (including speakers), the response was $59 \%$.

In 2018, the questionnaire was sent to 55 participants of teachers' trainings (including speakers), the response was $28 \%$.

The participants/respondents and their current position in the field of migrant and Roma related activities

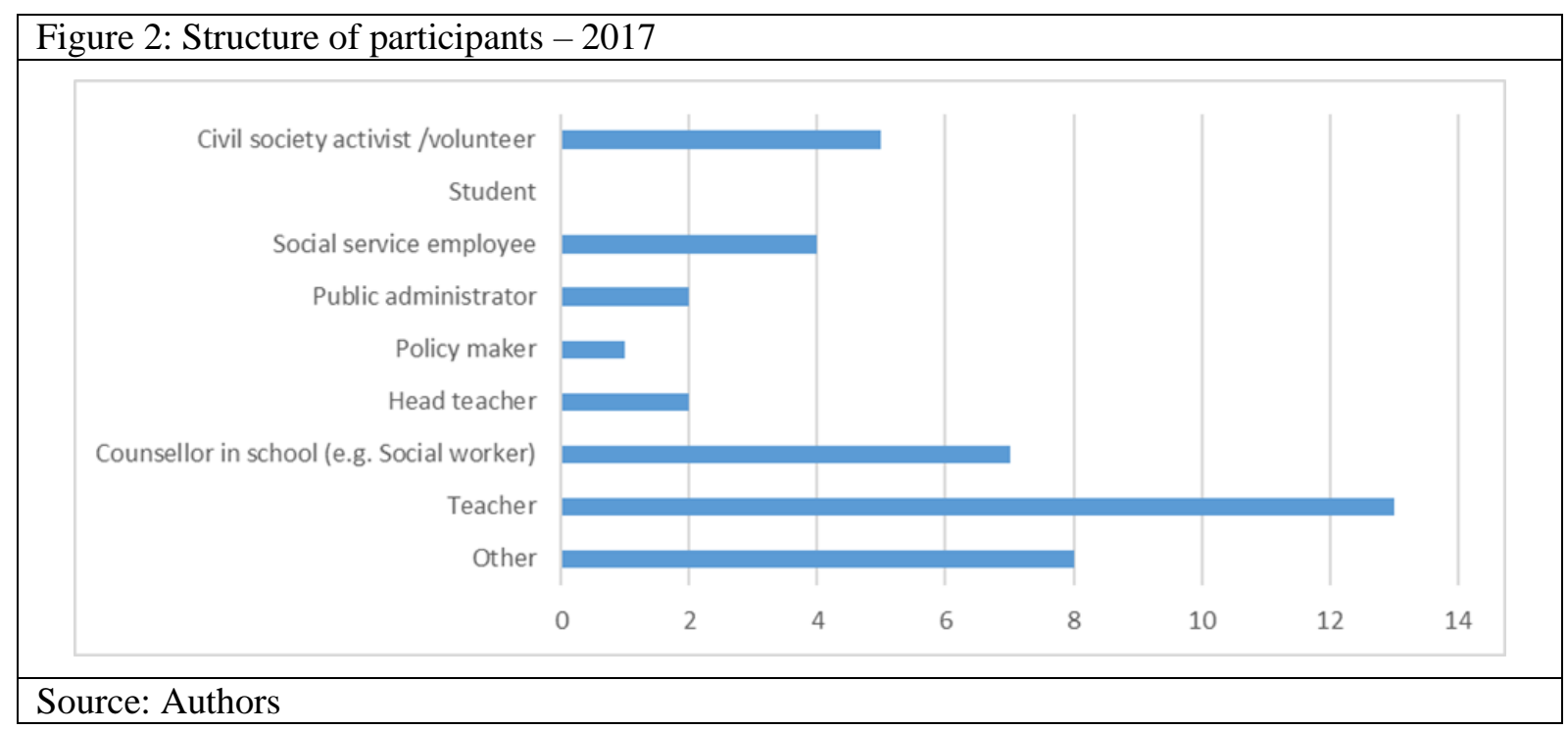




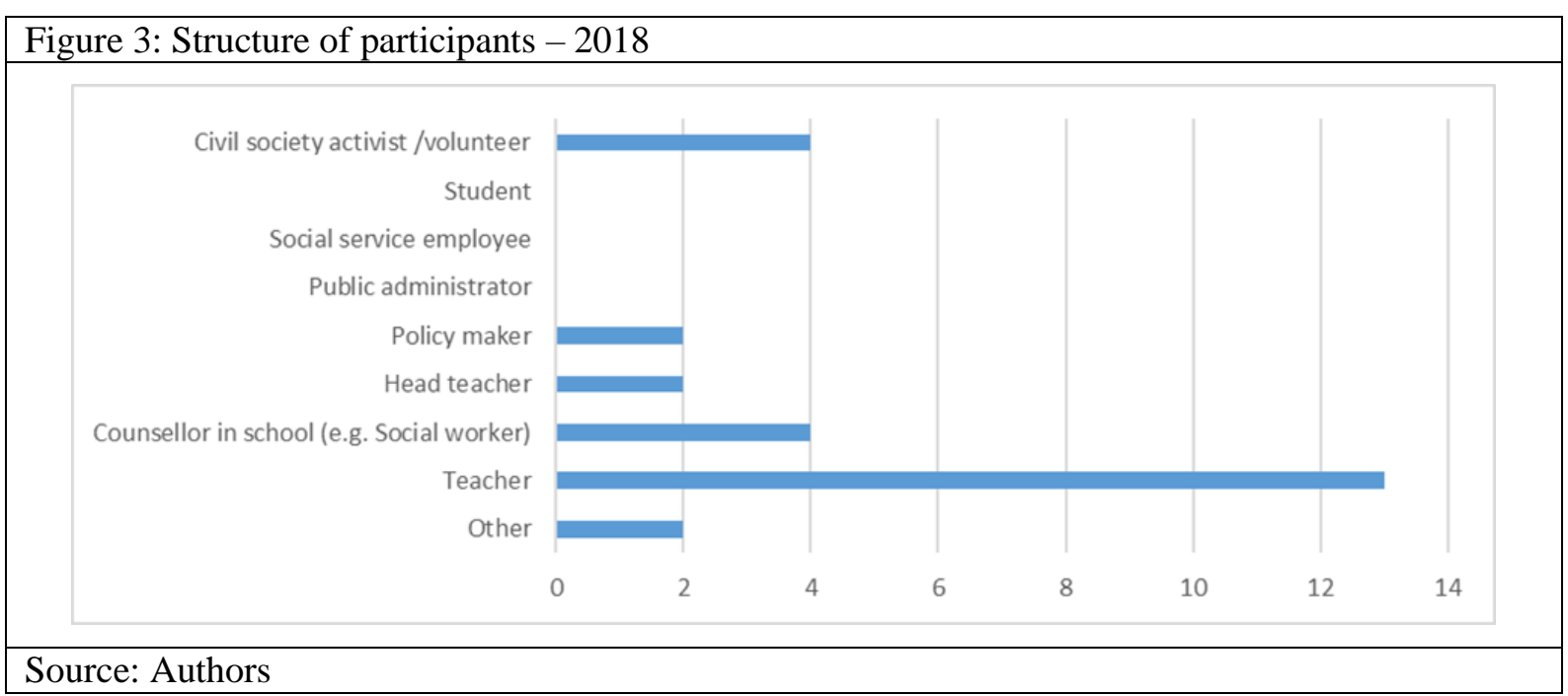

The majority of respondents in 2017 and in 2018 were teachers (as can be seen from Figures 1 and 2). Most respondents from 2017 had previous experience with specific methods; nevertheless, the majority of them had not been involved in working with Roma and/or migrant children. Analysis of the respondents from 2018 shows that most respondents $(73 \%)$ had previous experience with specific methods; $66 \%$ of respondents had been involved in working with migrant children; and $52 \%$ in working with Roma children.

The level of satisfaction with the seminars and suggestions for future activities of the project

The respondents were quite satisfied with the training in both years 2017, and 2018 (see Figure 3 and 4). In both years, participants were the most satisfied with opportunities to exchange experiences with peers and colleagues.

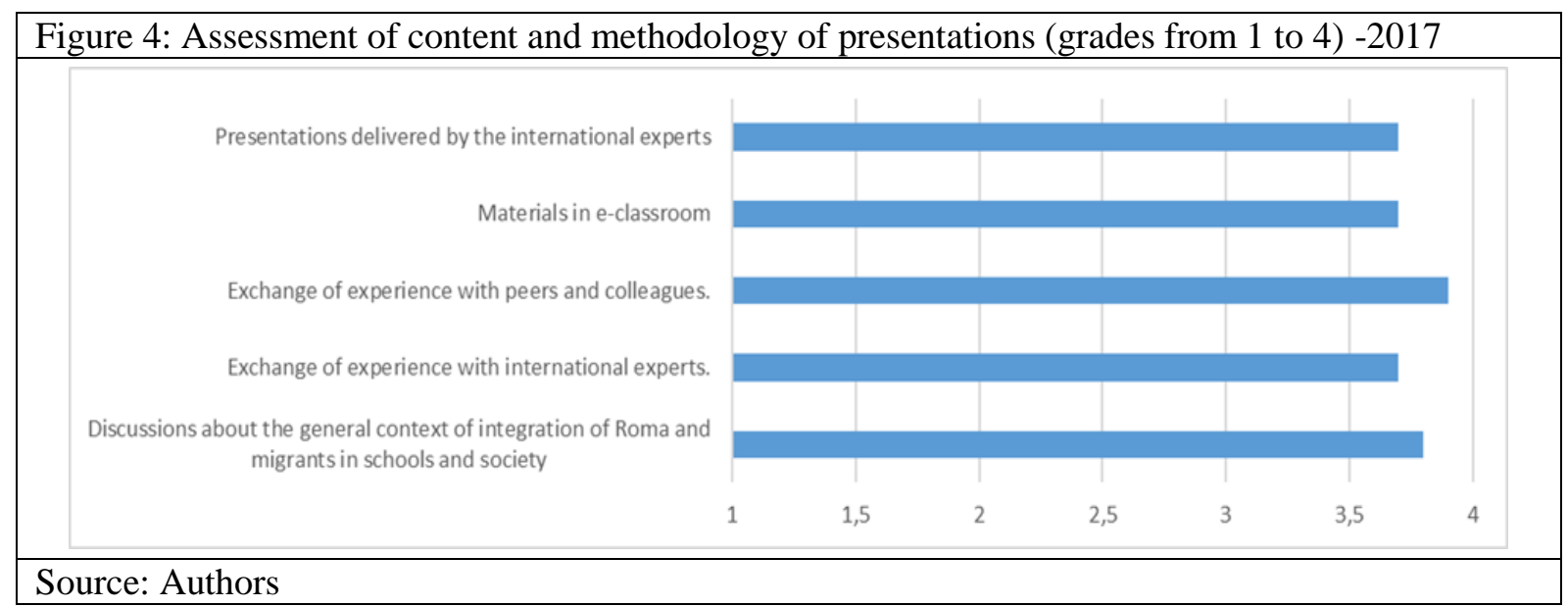

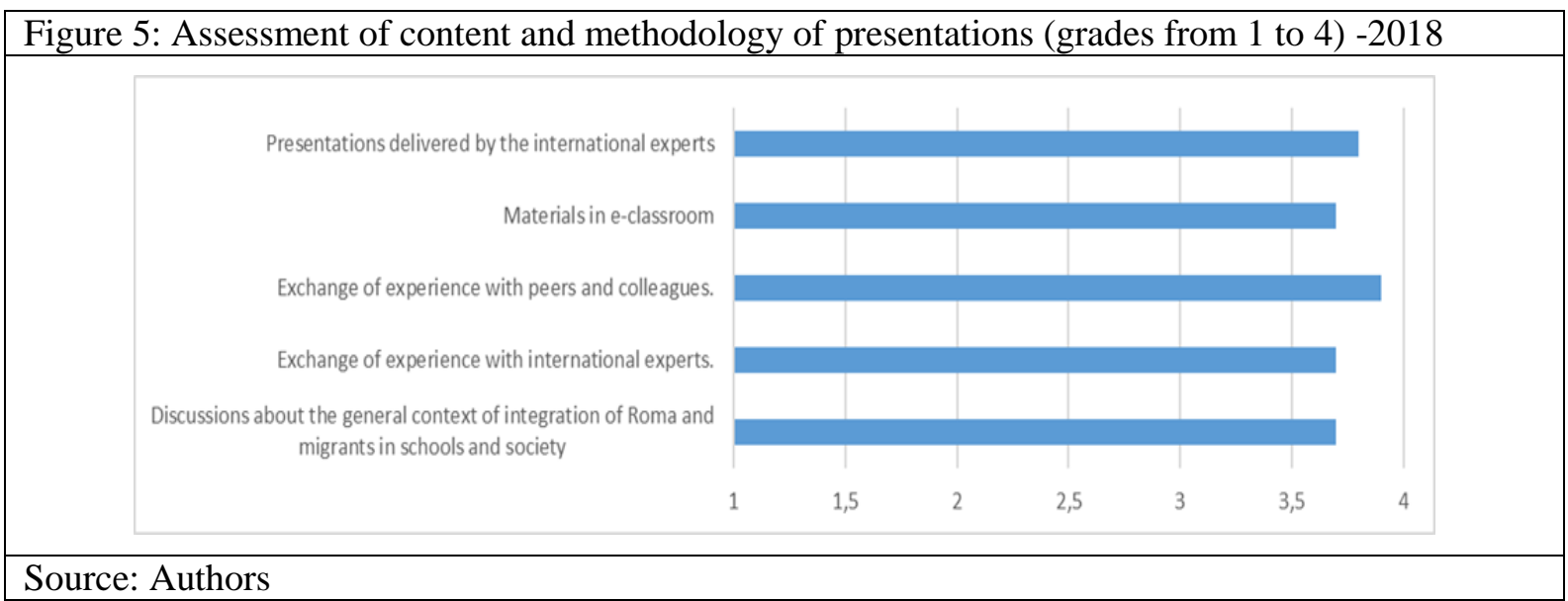


In the open questionnaire, we asked the participants about the most valuable lessons learned during the seminar. We sorted their answers into four categories, present in Table 1.

\begin{tabular}{|l|l|}
\hline \multicolumn{2}{|c|}{ Table 1: Lessons learned during the seminar - categories and typical answers } \\
\hline \multicolumn{1}{|c|}{ Category } & \multicolumn{1}{c|}{ Typical answers } \\
\hline $\begin{array}{l}\text { Role of } \\
\text { cooperation at } \\
\text { all levels }\end{array}$ & $\begin{array}{l}\text { State should do more to ensure better conditions for inclusion in schools, but a lot depends also on the } \\
\text { school (how schools can find solutions) and on teachers' competencies } \\
\text { It is necessary to cooperate at all levels }\end{array}$ \\
\hline $\begin{array}{l}\text { Exchange of } \\
\text { experience, } \\
\text { practices }\end{array}$ & $\begin{array}{l}\text { I liked the presentations of experiences from other countries. } \\
\text { I liked the presentation of good practices. } \\
\text { It was valuable to meet other colleagues that work in the area, having an opportunity to exchange } \\
\text { practical experiences with colleagues. }\end{array}$ \\
\hline $\begin{array}{l}\text { Involvement } \\
\text { of volunteers }\end{array}$ & $\begin{array}{l}\text { Volunteers can be very helpful to support inclusion in schools. } \\
\text { Student volunteering would be very welcome, especially for extra-curricular activities. } \\
\text { Interesting were the presentations of volunteering activities in Slovenian schools in the frame of } \\
\text { project RoMigSc }\end{array}$ \\
\hline Other & $\begin{array}{l}\text { Solidarity is an important value. } \\
\text { Approaching children from a more personal level is needed. } \\
\text { It is better to live in a refugee country than in a country where refugees are leaving. }\end{array}$ \\
\hline Source: Authors \\
\hline
\end{tabular}

Participant experiences working in multicultural environment, what are the advantages, and what the obstacles/problems

In the questionnaire we asked the participants about their advantaged which they may apply in a multicultural environment. We divided their answers into 3 groups, as can be seen from the Table 2 .

\begin{tabular}{|c|c|}
\hline Category & Typical answers \\
\hline $\begin{array}{l}\text { Knowledge and } \\
\text { experiences }\end{array}$ & $\begin{array}{l}\text { Long-time work with Roma and migrants/refugees. } \\
\text { Knowledge and Experience in this field, positive attitude. } \\
\text { Using innovative teaching methods, looking for solutions to the problem, personal relationship and } \\
\text { involvement. }\end{array}$ \\
\hline $\begin{array}{l}\text { Intercultural } \\
\text { competencies }\end{array}$ & $\begin{array}{l}\text { Acceptance and understanding of other cultures, empathy, patience. } \\
\text { Understanding of the cultural background, willingness to listen, awareness of differences. } \\
\text { Being able to accept differences, accepting marganilised groups. }\end{array}$ \\
\hline Other & I do not have experiences of working in such a class... \\
\hline
\end{tabular}

Table 3: Factors which may negatively influence the inclusion of migrant and Roma children in schools - categories and typical answers

\begin{tabular}{|l|l|}
\hline \multicolumn{1}{|c|}{ Category } & \multicolumn{1}{c|}{ Typical answers } \\
\hline Policy problems & $\begin{array}{l}\text { Incompatibility of policies and measures. } \\
\text { Things/solutions are moving too slow at the system level. } \\
\text { Too many children in the classroom. } \\
\text { We lack time, to many tasks and there is little time for individual work with parents and children. }\end{array}$ \\
\hline $\begin{array}{l}\text { Difficulties in } \\
\text { ensuring inclusion } \\
\text { of Roma/migrant } \\
\text { in classes }\end{array}$ & $\begin{array}{l}\text { Learning difficulties, lack of basic knowledge, lack of language knowledge. } \\
\text { Children that come from countries, whose language, culture in much different from Slovenian, } \\
\text { would need more time for adaptation } \\
\text { Low participation of the child's parents and the Roma community in school activities. } \\
\text { Non-acceptance of the environment (Roma). } \\
\text { Not understanding the language (migrants). }\end{array}$ \\
\hline $\begin{array}{l}\text { Lack of } \\
\text { knowledge, } \\
\text { competencies of } \\
\text { teachers }\end{array}$ & $\begin{array}{l}\text { Teachers and teachers' graduates do not know enough about ethnic minorities (Roma, migrants). } \\
\text { Changing the curriculum in teacher education. } \\
\text { On national level there are several trainings on inclusions, but a single teacher should attend } \\
\text { trainings on different topics (not only on one topic) and in this way get insight into inclusion in } \\
\text { more holistic way } \\
\text { Teacher shall be more involved in international exchanges - and also in this way enhance } \\
\text { multiculturalism }\end{array}$ \\
\hline Other & $\begin{array}{l}\text { Not enough good will, positive approach towards problems. } \\
\text { Very useful is the international dimension: to have an overview on how countries are facing } \\
\text { similar challenges ... }\end{array}$ \\
\hline Source: Authors & \\
\hline
\end{tabular}


On the other hand, there might be also some factors which may negatively influence the inclusion of migrant and Roma children in schools. On the question: Which is the biggest obstacle/problem in their work/ activities in a multicultural class/environment that may negatively influence inclusion, we received the following answers, that we grouped into four categories (Table 3 ).

\section{Policy recommendations from the implementation of teacher trainings 2018 in Slovenia, Spain, FYROM and Italy}

Below we present policy recommendations from teacher trainings that were organised in partner countries of the project RoMigSc in 2018.

\section{- SLOVENIA}

- Related to general aspects of inclusion of Roma/migrant children into education

- Understanding of cultural diversity and trust in migrant, Roma children should be supported and not stressed at all school system levels.

- Mobility of teachers shall be encouraged - as an important aspect of encouraging and developing multiculturalism.

- Good practices, experiences should be shared in the area.

- Multiculturalism and inclusion are supported by the state; but in many cases solutions are not sustainable (mostly in a form of projects), there is a need for more systematic solutions, which will last after the conclusion of the projects.

- Related specifically to Roma

- Need for better cooperativeness between the Roma community, parents and schools.

○ Related to volunteering

- Volunteers have important roles in helping migrants and Roma to integrate; such work needs to be more supported and systematically organised; schools need to show volunteers that they appreciate their work, time and energy they donate.

- SPAIN

- Related to general aspects of inclusion of Roma/migrant children into education

- It is essential to intervene at an early age for greater school integration of these groups.

- To put in value and share the practical examples of good practices.

- To put in value multicultural models of students, professionals and citizenship in general to observe the change towards a multicultural paradigm.

- To share examples and realities of educational work with other educational entities and meet classmates who live inside the school different experiences can allow to create networks of great value, even thinking in an European context.

- Create heterogeneous and interactive groups that strengthen the concept of diversity.

- Training of professionals and the provision of human and material resources to public entities that work with these target groups.

- Related specifically to Roma

- The understanding of different Roma cultures in Spain as diverse and dynamic is fundamental to working successfully.

- Related specifically to Migrants

- To act and intervene at early ages for greater integration and think about formulas that give continuity to the work done with minors when they reach the age of majority. 


\section{- FYROM}

- Related to general aspects of inclusion of Roma/migrant children into education

- Good practices, experiences should be shared in the area.

- Related specifically to Roma

- Roma children need to learn Roma language as a course in primary schools.

- The municipality should be interested in the problems of Roma children in schools.

- Teachers feel that the government and social workers should take care of the difficult situation of Roma families and children, because teachers cannot impact on the drop-out rate since parents do not listen to teachers.

- Problems with Roma children start from the family education.

- Special programs are needed and applied in some cases for pupils who cannot read and write.

- Teachers can use textbooks in more intercultural ways; they can use different approaches to explain content to students/pupils.

○ Related to volunteering

- Volunteers have an important role in helping Roma children to overcome difficulties in learning.

\section{- ITALY}

- Related to general aspects of inclusion of Roma/migrant children into education

- Concept of inter-culturalism is used especially at a theoretical level, teachers in many everyday situations cannot act by referring to it; in this respect it is important to support continuous trainings for teachers: where teachers can debate, learn from each other and from different renowned experts from the area, compare strategies, reflect, take the opportunity to get additional insight into the topic on inclusion; in order to support them to become more competent for everyday situations in multicultural classrooms.

- The overall importance of empathy, understanding, knowing and trust in migrant/Roma children should be stressed at all school system levels. The school system should be adapted to children's abilities and needs.

- Teachers' low expectations develop the low expectations of children.

\section{Conclusion}

From the results of the small-scale research conducted in Slovenia in 2017 and 2018, we can conclude that participants were in general very satisfied with the delivery of training; particularly they see it as an opportunity to exchange opinions and views with colleagues. Participants also gave feedback on how they see inclusion in schools; and where improvements are still needed. On the level of teachers competencies we can summarize the needs of improvements as follows: teachers and students (teaching profession) shall improve their knowledge on the issues related to minorities (Roma, migrants); curricula in teacher education shall be changed, so that teachers learn about intercultural competencies already during the studies, teachers shall attend trainings that give insight into inclusion in a more holistic way (not attending only one specialized training but more trainings on inclusion); teachers shall be more involved in international exchanges - and also in this way enhance multiculturalism.

Also policy recommendations, which were formulated after the delivery of teacher trainings in other partner countries (North Macedonia, Spain, Italy), show that intercultural competencies of teachers are of key importance, if we want to make progress in overcoming intercultural inequalities, ensuring equal opportunities and equity and the equal participation of various social groups in culturally diverse schools (and wider society) is key.

However, we cannot expect only from teachers, to ensure the implementation of the principle of interculturalism. For the implementation of intercultural education, schools should be considered as a social system consisting of a series of components and variables (e.g. relations and views of the entire school 
staff, curriculum, school politics or culture, hidden curricula, learning styles, placement and links with the local community, methods of examining skills, learning materials, learning styles and strategies, etc.). To implement an effective intercultural education and achieving long-term changes at the school level teachers need tbe full support from school principals, and support from outside the school in government policy, where the government should ensure that these topics are integrated into study programmes that educate future teachers (Bešter and Medvešek, 2016; see also Novak Trunk, Čepar and Trunk, 2016). It is also very important that teachers are committed to enhancing their multicultural competences by attending the trainings - through the trainings they not only learn about the topic; but have the opportunity to exchange their experiences/practices with other colleagues and compare strategies.

\section{References}

Bešter, R., Medvešek, M. (2016). Medkulturne kompetence učiteljev: primer poučevanja romskih učencev [Intercultural competencies of teachers: an example of teaching Roma pupils]. Sodobna Pedagogika, 67(2), 26-44.

Deardorff, D. K. (2006). Identification and Assessment of Intercultural Competence as a Student Outcome of Internationalization. Journal of Studies in International Education 10(3), 241-266.

ISA institute (2015). Razvijamo medkulturnost kot novo obliko sobivanja [We are developing interculturalism as a new form of coexistence]. Retrieved from http://www.mizs.gov.si/fileadmin/mizs.gov.si/pageuploads/podrocje/kadri/tif/Razvijamo _medkulturnost_kot_novo_obliko_sobivanja_-_Zbornik.pdf

Ministry of Education, Science and Sport, Republic of Slovenia. (2019). Izzivi medkulturnega sobivanja -Za medkulturno sobivanje 2016-2021 [Challenges of Intercultural Coexistence 2016-2021]. Retrived from http://www.medkulturnost.si/

Novak Trunk, A., Čepar, Ž., Trunk, A. (2016). The role of expected years of schooling among life expectancy determinants. International journal of innovating and learning, 20(1), 85-99.

OECD. (2009). Creating Effective Teaching and Learning Environments. First results from TALIS. Retrieved from http://www.oecd.org/education/school/43023606.pdf.

OECD. (2018). The Resilience of Students with an Immigrant Background. Retrieved from https://www.oecdilibrary.org/education/the-resilience-of-students-with-an-immigrant-background_9789264292093-en

Trunk, A., Kočar, S. Trunk Širca, N. (2017). Education and training for financial literacy : the role of banks - case study Slovenia. International journal of innovating and learning, 22( 3), 385-406. 